\title{
Rainfall interception by selected plants in the Chihuahuan Desert
}

\author{
M.K. WOOD, T.L. JONES, AND M.T. VERA-CRUZ
}

Authors are professor, Department of Animal and Range Sciences, associate professor, Department of Agronomy and Horticulture, New Mexico State University, Las Cruces, N.M. 88003; and former graduate student from Cape Verde Islands.

\begin{abstract}
Water budget modeling usually requires quantification of all possible processes of the hydrologic cycle. This includes rainfall interception. The purpose of this study was to estimate the potential amounts of water transferred back to the atmosphere from interception for some common plants found in the Chihuahuan desert. Fifty plants of many sizes representing 10 common species of the Chihuanhuan Desert were chosen for evaluation. Plants were submerged in a $2 \times 2 \mathrm{~m}$ tank filled with water. After submersion, the plants were weighed, and the difference in weight was recorded as the maximum water storage capacity of the plant's canopy. Plants were also measured for maximum and minimum crown diameter $(\mathrm{cm})$, height $(\mathrm{cm})$, green weight $(\mathrm{g})$ at time of submersion, and oven-dry weight $(\mathrm{g})$. The forb, grass, and shrub species had different variables included in the prediction equations. Dry and green weight were the 2 variables which appear to have the strongest relationship with the amount of water intercepted for all species. Of the 7 grass species evaluated, dry and green weight were part of all equations, and height was included in only 2 equations.
\end{abstract}

Key Words: hydrologic model, crown diameter, green weight, dry weight, plant height, evaporation

Rainfall interception is the process of plant leaves and stems catching and retaining precipitation within the vegetation canopy. Intercepted precipitation can be returned to the atmosphere through evaporation or channeled to the ground by stem flow or foliar drip (Teklehaimanot et al. 1991). This process may change the quantity, quality, and distribution of precipitation which reaches the soil surface.

For most storms, interception results in less water falling through the canopy and reaching the ground. However, clouds or fog may envelop plant communities nearly everywhere, especially in coastal regions (Harr 1983), mountains, and tropical areas (Zadroga 1981). Individual water droplets may be so small, they remain suspended in the air rather than falling to the ground. Clouds of water droplets move through the vegetation and deposits the droplets on all sides of projecting vegetation. Instead of precipitation being lost in the interception process, there is a precipitation gain, and net precipitation exceeds precipitation above the canopy.

Manuscript accepted 15 Mar. 1997.

\section{Resumen}

El modelaje de acumulación de agua generalmente requiere de una cuantificación de todos los procesos posibles del ciclo hidrológico. Esto incluye la intercepción de la lluvia. El proposito de este estudio fué estimar las cantidades potenciales de agua devueltas a la atmosfera por la intercepción de algunas plantas que comunmente se encuentran en el desierto Chihuahuense. Cincuenta plants de diferentes tamaños que representan 10 especies comunes del desierto Chichahuense fueron escogidas para la evaluación. Las plantas fueron sumergidas en un tanque de $2 \times 2 \mathrm{~m}$ lleno con agua. Después de ser sumergias, las plants fueron pesadas y la diferencia en peso fué registrada como la capacidad máxima de almacenaje de agua por la cobertura vegetal de las plantas. De las plantas también se cuantificó el diametro máximo y mínimo de la copa $(\mathrm{cm})$, la altura $(\mathrm{cm})$, el peso del material verde (g) al tiempo de ser sumergido, y el peso después de ser secado en el horno (g). Las especies de hierbas, zacates $y$ arbustos tuvieron diferentes variables incluídas en las ecuaciones de predicción. Los pesos del material seco y verde fueron las dos variables que parece ser tuvieron la relación más fuerte con la cantidad de agua interceptada por todas las especies. De las 7 especies de zacates evaualdas, el peso del material seco y verde formó parte de toas las ecuaciones, y la altura fue incluída solamente en 2 ecuaciones.

Any analysis of water delivery to plant canopies requires data on the pertinent characteristics of foliage and branch structure. The impact conditions from precipitation should be measured as well as the build-up of rain and snow. These kinds of data are rare. For instance, Miller (1977) reviewed several year's literature on interception of snowfall. Virtually the entire recorded literature only included 110 studies. Only 1 reported concurrent measurements of the canopy, input of snow, and amounts of snow that were intercepted. Miller concluded that the plant characteristics that determine the form of storage, strength, and stability of their physical support, their thermal surrounding, and conditions under which inputs and outputs of rain and snow take place are generally not known. Data on the rate of precipitation, storm temperature, wind speed, and mass of stored water related to interception are scant and sporadic. Interception knowledge is important in studies of the other parts of the hydrologic cycle. As an example, more than 100 studies have probably been conducted to determine infiltration rates of rangelands by applying simulated rainfall, catching the resultant runoff, and ignoring the interception. 
Most interception studies have been conducted on trees. Reliable interception data for shrubs, grasses, forbs, and other herbaceous plants are difficult to obtain. Their values are probably less in most instances than trees (Brooks et al. 1992). Interception values may not be as low as the relative plant heights suggest, however. The leaf surface per area of canopy for many herbaceous plants often approaches that of shrubs and trees.

A common way to express interception is on an average annual basis. Branson et al. (1981) refer to dozens of studies where a percentage of the average annual precipitation is reported as being intercepted. When only the percentage of annual precipitation resulting in interception is reported for a vegetation type or community, the report lacks necessary information. One useful approach is that of Tromble (1983a, 1983b). Individual creosotebushes (Larrea tridentata (D.C.) Cav.) were measured for intercepted water throughout a rainfall event and correlated with crown cover, shrub height, shrub green weight, green-weight of stems, oven-dry weight of stems, green-weight of leaves, ovendry weight of leaves, number of stems, leaf area, and shrub volume. Predictive models for the species were determined that allowed calculation of interception for individual plants. An individual plant community can be sampled for individual plant characteristics and density to determine an interception value for that particular creosotebush community.

It has often been observed that interception is as great at the beginning of a storm as the area under a plant, such as a tree with much foliage, remains dry. As time passes, the interception capacity or potential of the plant is reached and the area under the plant receives precipitation similar to the area between plants. This process can be expressed as a model (Fig. 1). At the beginning of the precipitation event, virtually all water is intercepted. A maximum is reached when the cumulative interception no longer increases because the amount of throughfall, foliar drip, and stemflow equal the amount of precipitation. Most evaporation takes place after the event has ceased. The amount of time between the beginning of the precipitation event and the time needed to reach the maximum amount of precipitation being intercepted varies with each plant and storm. It is species and size dependent. The amount of cumulative interception (the highest point on the curve) also varies with each plant.

The purpose of this study was to determine the potential amount of water intercepted and evaporated for some common Chihuahuan desert plants.

\section{Methods}

Ten common species of the Chihuahuan Desert, listed in Table 1 , were chosen for evaluation. Fifty plants of many sizes of each species were cut to ground level near Las Cruces, N.M. near the end of the monsoon and growing season (August). Immediately following collection, plants were taken to a laboratory for immediate evaluation.

Aston (1979) stated maximum canopy saturation or canopy storage is the most important variable in the interception process. Leonard (1965) stated that storage capacity is a function of leaf area index and surface tension forces resulting from leaf surface configurations. However, each of these are difficult to measure for an entirc plant. Plant characteristics that are easier to measure and related to leaf area index and surface tension forces resulting from leaf surface configurations include plant green weight, dry weight, height, and crown diameter. Plants were immediately transported to a laboratory and cleaned of foreign debris, and the roots were pruned to avoid water interception by roots. Only plants of 1 species were clipped in each collection trip, and measurements were made before turgor loss occurred.

Many studies have used simulated rainfall to determine interception (Pitman 1989, Thurow et al. 1987, Tromble 1983a, Tromble 1983b). Unless these plants were clipped and then left in situ, their interception values are probably lower than values from
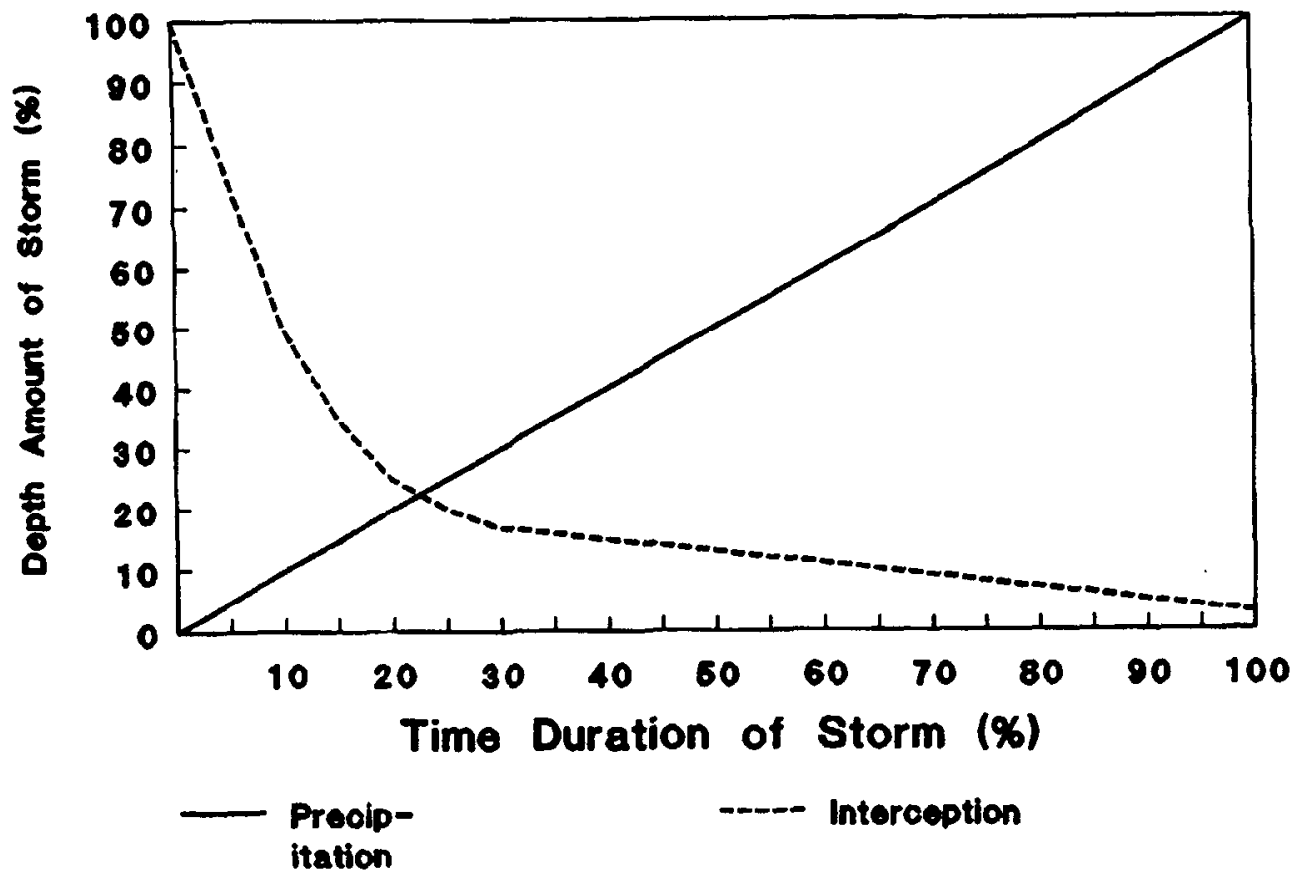

Fig. 1. Precipitation and interception of a single storm event. 
Table 1. Plant species chosen for interception.

\section{Forb:}

Russian thistle

Grasses:

Black grama

Sideoats grama

Bush Muhly

Red threeawn

Mesa dropseed

Lehmann lovegrass

Cane bluestem

Shrubs:

Broom snakeweed

Fourwing saltbush

natural rainfall at the same rates. Calder (1986) attributes interception to the stochastic manner in which individual elements of the surface of the tree are struck and wetted by individual raindrops. Herwitz (1985) explained that water not only comes to the plant from above but a plant's interception storage appears asymptotic because of the gradual accumulation of rain splash on the sheltered undersides of leaves and branches. Because of this multi-directional accumulation of precipitation, each plant was weighed by attaching the top of each plant to a nylon line below a suspended analytical balance. Plants were then submerged in a 2 $\times 2 \mathrm{~m}$ water tank. Immediately after submersion, plants were removed from the water tank until after any foliar dripping or stemflow occurred and re-weighed. The difference in weight was recorded as the maximum water holding or storage capacity of the plant's canopy. This value is used to estimate the maximum amount of interception that could occur during rainfall. Plants were also measured for maximum and minimum crown diameters (cm), height $(\mathrm{cm})$, green weight $(\mathrm{g})$ at time of submersion, and oven-dry weight $(\mathrm{g})$. Before obtaining oven-dry weight, the plants were put in an oven for a period of 5 days at $60^{\circ} \mathrm{C}$.

Linear regression analysis was used to determine which independent variables (crown diameter, height, green weight, and dry weight) were most highly correlated with potential interception. Stepwise regression analysis was used to weigh the importance of each independent variable so that a multiple-factor predictive equation could be constructed for use in hydrologic models.

\section{Results and Discussion}

\section{Russian Thistle}

Individual Russian thistles ranged from large to small (Table 2) relative to green weights, dry weights, crown diameters, and heights. Stubbendieck et al. (1992) stated that this species grows to $80 \mathrm{~cm}$ tall. Therefore, the tallest samples for this study $(68 \mathrm{~cm})$ approached the maximum for this species. The mean values for these variables were closer to the minimum than to the maximum values, and the large coefficients of variation for green and dry weights indicate that most of the sample represented many sizes of Russian thistles.

Dry and green weights were most correlated with potential interception (Table 3) while height and diameter had low coefficients of determination $\left(R^{2}\right)$. T-values were high which indicates a high probability that 1 or more of the coefficients is not zero. Variables selected for inclusion in the prediction equation includ- ed dry weight, diameter, and height. The equation is:

$$
\begin{aligned}
\hat{\mathbf{y}} & =10.06+0.429 \text { (dry wt. } \mathrm{g})-0.99 \text { (diameter } \mathrm{cm}) \\
& +0.69 \text { (height } \mathrm{cm})
\end{aligned}
$$

where $\hat{y}$ is the maximum weight $(g)$ of water that each plant can hold on its surface at any one time. The $R^{2}$ value is 0.806 and the standard error is 14.44 .

The ratio of intercepted water to green weight and dry weight (Table 4) is low for Russian thistle compared to other species. This is attributed to growth form and plant surface characteristics sincc Russian thistle is much-branched, ascending or spreading, rounded in shape with linear blades (Stubbendieck et al. 1992).

\section{Black Grama}

Individual black grama plants ranged from large to small (Table 2) relative to green weights, dry weights, and crown diameters. Stubbendieck et al. (1992) stated that this species grows to $60 \mathrm{~cm}$ tall. Therefore, the tallest samples for this study $(52 \mathrm{~cm})$ approached the maximum for this species. Crown diameters and plant heights were not as different nor as variable as green and dry weights for this species. The mean values for these variables were closer to the minimum than to the maximum values, and the coefficients of variation indicate that the sample represented many plants whose sizes were close to the mean. The best prediction equation for black grama with variables selected for inclusion is:

$$
\begin{aligned}
\hat{\mathbf{y}} & =1.55+0.646 \text { (green wt. } \mathbf{g} \text { ) } \\
\mathbf{R}^{2} & =0.976 \quad \text { Std. Error }=1.35
\end{aligned}
$$

The ratio of intercepted water to green weight and dry weight (Table 4) is high for black grama compared to other species. This is attributed to growth form and plant surface characteristics since black grama is ascending to decumbent, spreading, wiry, slender, woolly pubescent on lower internodes with the base swollen and woolly (Stubbendieck et al. 1992).

\section{Sideoats Grama}

Individual sideoats grama plants ranged from large to small (Table 2) relative to green weights, dry weights, and crown diameters. Stubbendieck et al. (1992) stated that this species grows to $100 \mathrm{~cm}$ in wet regions and Gay et al. (1980) gave $75 \mathrm{~cm}$ as its maximum height in the Chihuahuan desert. Therefore, the tallest samples for this study $(68 \mathrm{~cm})$ approached the maximum for this species in the area where it was collected. Crown diameters and plant heights were not as different nor as variable as green and dry weights for this species. The mean values for green and dry weights were closer to the minimum than the maximum values, and the coefficients of variation indicate that the sample represented many plant sizes. The mean values for crown diameter and plant height were about as close to the maximum as to the minimum values, and coefficients of variation were not as high for these variables as for green and dry weights. The best prediction equation for sideoats grama with variables selected for inclusion is:

$$
\begin{aligned}
& \hat{\mathrm{y}}=-6.782-0.139 \text { (green wt. } \mathrm{g} \text { ) } \\
& +0.546(\text { dry wt. } \mathrm{g})+0.357 \text { (diameter } \mathrm{cm}) \\
& +0.174 \text { (height } \mathrm{cm} \text { ) } \\
& \mathrm{R}^{2}=0.964 \quad \text { Std. Error }=2.897
\end{aligned}
$$

The ratio of intercepted water to green weight and dry weight (Table 4) is low for sideoats grama compared to other grass species. This is attributed to growth form and plant surface char- 
Table 2. Maximum, minimum, and mean values, and coeficients of variation of intercepted water, green weight, dry weight, crown diameter, and plant height of each species.

\begin{tabular}{|c|c|c|c|}
\hline $\begin{array}{l}\text { Maximum } \\
\text { value }\end{array}$ & $\begin{array}{c}\text { Minimum } \\
\text { value }\end{array}$ & $\begin{array}{l}\text { Mean } \\
\text { value }\end{array}$ & $\begin{array}{c}\text { Coefficient } \\
\text { Variation } \\
(\%)\end{array}$ \\
\hline
\end{tabular}

Russian thistle

Intercepted

Water weight (g)

Green weight $(\mathrm{g})$

Dry weight $(\mathrm{g})$

189

Crown Diameter $(\mathrm{cm})$

Height (cm)

Black grama

Intercepted

Water weight (g)

Green weight $(\mathrm{g})$

Dry weight $(g)$

Crown Diameter $(\mathrm{cm})$

Height (cm)

Sideoats grama

Intercepted

Water weight (g)

Green weight ( $g$ )

Dry weight (g)

Crown Diameter (cm)

Height (cm)

Bush Muhly

Intercepted

Water weight (g)

Green weight ( $g$ )

Dry weight (g)

Crown Diameter (cm)

Height (cm)

Red threeawn

Intercepted

Water weight (g)

Green Weight (g)

Dry weight (g)

Crown Diameter $(\mathrm{cm})$

Height (cm)

Mesa dropseed

Intercepted

Water weight $(\mathrm{g})$

Green weight $(g)$

Dry weight (g)

Crown Diameter $(\mathrm{cm})$

Heighl (cm)

Lehmann lovegrass

Intercepted

Water weight (g)

Green weight (g)

Dry weight ( $g$ )

Crown Diameter (cm)

Height (cm)

Cane bluestem

Intercepted

Water weight $(\mathrm{g})$

Green weight $(\mathrm{g})$

Dry weight (g)

Crown Diameter (cm)

Height (cm)

Broom snakeweed

Intercepted

Waler weight $(g)$

Green weight (g)

Dry weight (g)

Crown Diameter $(\mathrm{cm})$

Height (cm)
Fourwing saltbush

Intercepted

Water weight (g)

Green weight $(\mathrm{g})$

Dry weight $(\mathrm{g})$

Height $(\mathrm{cm})$

1,200

100

100

17
70
100
100

$\begin{array}{rrr}7 & 60 & 110 \\ 20 & 209 & 152 \\ 13 & 120 & 149 \\ 16 & 39 & 44 \\ 20 & 49 & 35\end{array}$

acteristics since sideoats grama has culms that are round and smooth, sheaths that are round and glabrous, and blades that are flat and linear (Stubbendieck et al. 1992).

\section{Bush Muhly}

Individual bush muhly plants ranged from large to small (Table 2) relative to green weights, dry weights, and crown diameters. Gay et al. (1980) stated that this species grows to $90 \mathrm{~cm}$ tall. The tallest samples for this study $(52 \mathrm{~cm})$ were considerably less than the maximum for this species. Plant heights were not as different nor as variable as green and dry weights and crown diameters for this species. The mean values for green and dry weights and crown diameters were closer to the minimum than the maximum values, and the coefficients of variation indicate that the sample represented many plant sizes. The mean for plant height was about as close to the maximum as to the minimum values, and coefficient of variation was not as high for this variable as for green and dry weights and crown diameter. The best prediction equation for bush muhly with variables selected for inclusion is:

$$
\begin{aligned}
& \hat{y}=-0.98+0.729 \text { (dry wt. } g \text { ) } \\
& R^{2}=0.966 \text { Std. Error }=7.30
\end{aligned}
$$

The ratio of intercepted water to green weight and dry weight (Table 4) is low to moderate for bush muhly compared to other grass species. This is attributed to growth form and plant surface characteristics since bush muhly has culms that are spreading to ascending from a woody, knotty base, and blades that are flat, thin, acuminate, and scabrous (Stubbendieck et al. 1992).

\section{Red Threeawn}

Individual red threeawn plants ranged from large to small (Table 2) relative to green weights, dry weights, and crown diameters. Gay et al. (1980) stated that this species grows to $50 \mathrm{~cm}$ tall. The tallest samples for this study $(40 \mathrm{~cm})$ were less than the maximum for this species. Plant heights were not as different nor as variable as green and dry weights and crown diameters for this species. The mean values for green and dry weights and crown diameters were closer to the minimum than to the maximum values, and the coefficients of variation indicate that the sample represented many plant sizes. The mean for plant height was about as close to the maximum as to the minimum values, and coefficient of variation was not as high for this variable as for green and dry weights and crown diameter. The best predication equation for red threeawn with variables selected for inclusion is:

$$
\begin{aligned}
& \hat{y}=-1.054+0.938 \text { (green wt. g) } \\
& +1.652 \text { (dry wt. g) } \\
& R^{2}=0.975 \quad \text { Std. Error }=2.470
\end{aligned}
$$

The ratio of intercepted water to green weight and dry weight (Table 4) is moderate for red threeawn compared to other grass species. This is attributed to growth form and plant surface characteristics since red threeawn's growth habit is cespitose or closely tufted, and its sheaths are glabrous to weekly scabrous, and its blades are scabrous and mostly basal (Stubbendieck et al. 1992). 
Table 3. Correlation analysis $(N=50)$ for each species with interception being the dependent variable.

\begin{tabular}{|c|c|c|c|c|c|c|c|c|}
\hline \multirow[b]{3}{*}{ Species } & \multicolumn{8}{|c|}{ Variables } \\
\hline & \multicolumn{2}{|c|}{ Green Weight } & \multicolumn{2}{|c|}{ Dry Weight } & \multicolumn{2}{|c|}{ Height } & \multicolumn{2}{|c|}{ Diameter } \\
\hline & $\mathbf{R}^{2}$ & t-value & $\mathbf{R}^{2}$ & t-value & $\mathbf{R}^{2}$ & t-value & $\mathbf{R}^{2}$ & t-value \\
\hline $\begin{array}{r}\text { Russian } \\
\text { thistle }\end{array}$ & 0.71 & 10.72 & 0.77 & 12.57 & 0.33 & 4.82 & 0.36 & 5.14 \\
\hline $\begin{array}{l}\text { Black } \\
\text { grama }\end{array}$ & 0.95 & 31.05 & 0.90 & 21.03 & 0.23 & 0.03 & 0.67 & 9.97 \\
\hline $\begin{array}{r}\text { Sideoats } \\
\text { grama }\end{array}$ & 0.80 & 13.74 & 0.88 & 18.81 & 0.27 & 3.88 & 0.56 & 7.91 \\
\hline $\begin{array}{l}\text { Bush } \\
\text { muhly }\end{array}$ & 0.91 & 22.28 & 0.93 & 26.01 & 0.38 & 1.62 & 0.78 & 12.86 \\
\hline $\begin{array}{l}\text { Cane } \\
\text { bluestem }\end{array}$ & 0.88 & 18.69 & 0.88 & 19.13 & 0.20 & 0.91 & 0.85 & 16.73 \\
\hline $\begin{array}{l}\text { Lehmann } \\
\text { lovegrass }\end{array}$ & 0.86 & 17.41 & 0.86 & 17.02 & 0.46 & 19.43 & 0.58 & 8.16 \\
\hline $\begin{array}{l}\text { Mesa } \\
\text { dropseed }\end{array}$ & 0.88 & 18.41 & 0.90 & 20.72 & 0.34 & 0.84 & 0.65 & 10.26 \\
\hline $\begin{array}{l}\text { Red } \\
\text { thrceawn }\end{array}$ & 0.94 & 28.62 & 0.96 & 34.95 & 0.44 & 3.18 & 0.76 & 14.97 \\
\hline $\begin{array}{l}\text { Broom } \\
\text { snakeweed }\end{array}$ & $d^{0.59}$ & 8.32 & 0.78 & 13.42 & 0.49 & 6.76 & 0.53 & 7.35 \\
\hline $\begin{array}{l}\text { Fourwing } \\
\text { saltbush }\end{array}$ & 0.94 & 28.63 & 0.95 & 29.86 & 0.52 & 7.15 & 0.78 & 12.15 \\
\hline
\end{tabular}

\section{Mesa Dropseed}

Individual mesa dropseed plants ranged from large to small (Table 2) relative to green weights, dry weights, and crown diameters. Gay et al. (1980) stated that this species grows to $75 \mathrm{~cm}$ tall. Therefore, the tallest samples for this study $(70 \mathrm{~cm})$ approached the maximum for this species. Plant heights were not as different nor as variable as green and dry weights and crown diameters for this species. The mean values for green and dry weights and crown diameters were closer to the minimum than to the maximum values, and the coefficients of variation indicate that the sample represented many plant sizes. The mean for plant height was closer to the maximum than to the minimum value, and coefficient of variation was not as high for this variable as for green and dry weights and crown diameter. The best prediction equation for mesa dropseed with variables selected for inclusion is:

$$
\begin{aligned}
\hat{y}= & -1.96+0.499 \text { (dry wt. } g) \\
& +0.406 \text { (diameter cm) } \\
R^{2} & =0.953 \text { Std. Error }=4.091
\end{aligned}
$$

The ratio of intercepted water to green weight and dry weight (Table 4) is moderate for mesa dropseed compared to other grass species. This is attributed to growth form and plant surface characteristics since mesa dropseed's growth habit is tufted with smooth leaf sheaths and a relatively high ratio of stems to leaves (Gay et al. 1980).

\section{Lehmann Lovegrass}

Individual Lehmann lovegrass plants ranged from large to small (Table 2) relative to green weights, dry weights, and crown diameters. Gould (1975) stated that this species grows to $75 \mathrm{~cm}$ tall. Therefore, the tallest samples for this study $(70 \mathrm{~cm})$ approached the maximum for this species. Plant heights were not as different nor as variable as green and dry weights and crown diameters for this species. The mean values for green and dry weights, crown diameters, and plant heights were closer to the minimum than to the maximum values, and the coefficients of variation indicate that the sample represented many plant sizes. The coefficient of variation was not as high for Lehmann lovegrass height as for green and dry weights and crown diameter. The best prediction equation for Lehmann lovegrass with variables selected for inclusion is:

$$
\begin{aligned}
& \hat{y}=-3.38+0.205 \text { (dry wt. } g \text { ) } \\
&+0.319 \text { (height cm) } \\
& R^{2}=0.950 \text { Std. Error }=5.10
\end{aligned}
$$

The ratio of intercepted water to green weight and dry weight (Table 4) was low for Lehmann lovegrass compared to other grass species. This is attributed to growth form and plant surface characteristics since Lehmann lovegrass' branches are stiffly ascending to spreading, and its inflorescence is an open panicle (Gould 1975).

\section{Cane Bluestem}

Individual cane bluestem plants ranged from large to small (Table 2) relative to green weights, dry weights, and crown diameters. Gay et al. (1980) stated that this species grows to $120 \mathrm{~cm}$ tall. Therefore, the tallest samples for this study $(111 \mathrm{~cm})$ approached the maximum for this species. Plant heights were not as different nor as variable as green and dry weights and crown diameters for this species. The mean values for green and dry weights, crown diameters, and plant heights were closer to the minimum than to the maximum values, and the coefficients of variation indicate that the sample represented many plant sizes. The coefficient of variation was not as high for cane bluestem height as for green and dry weights and crown diameter. The best prediction equation for cane bluestem with variables selected for inclusion is:

$$
\begin{aligned}
& \hat{y}=41.025-5.441 \text { (green wt. g) } \\
& +5.832 \text { (dry wt. g) }+3.583 \text { (diameter cm) } \\
& R^{2}=0.969 \quad \text { Std. Error }=11.45
\end{aligned}
$$

The ratio of intercepted water to green weight and dry weight (Table 4) was moderate for cane bluestem compared to cther

Table 4. Ratio of intercepted water (g) to green weight (g), dry weight (g), crown diameter (cm), and plant height (cm) for each species.

\begin{tabular}{lcccc}
\hline Species & $\begin{array}{c}\text { Intercepted } \\
\text { water/green } \\
\text { weight }\end{array}$ & $\begin{array}{c}\text { Intercepted } \\
\text { water/dry } \\
\text { weight }\end{array}$ & $\begin{array}{c}\text { Intercepted } \\
\text { water/crown } \\
\text { diameter }\end{array}$ & $\begin{array}{c}\text { Intercepted } \\
\text { water/plant } \\
\text { height }\end{array}$ \\
\hline $\begin{array}{c}(\mathrm{g} / \mathrm{g}) \\
\text { Russian } \\
\text { thistle }\end{array}$ & 0.08 & $\begin{array}{c}(\mathrm{g} / \mathrm{g}) \\
(\mathrm{g} / \mathrm{cm})\end{array}$ & $\begin{array}{c}(\mathrm{g} / \mathrm{cm}) \\
0.57\end{array}$ \\
$\begin{array}{l}\text { Black grama } \\
\begin{array}{c}\text { Sideoats } \\
\text { grama }\end{array}\end{array}$ & 0.76 & 0.79 & 1.72 & 0.30 \\
$\begin{array}{c}\text { Bush muhly } \\
\text { Red threeawn }\end{array}$ & 0.33 & 0.49 & 1.46 & 0.41 \\
$\begin{array}{c}\text { Mesa } \\
\text { dropseed }\end{array}$ & 0.60 & 0.70 & 0.79 & 0.69 \\
$\begin{array}{c}\text { Lehmann } \\
\text { lovegrass }\end{array}$ & 0.62 & 0.67 & 1.44 & 0.53 \\
$\begin{array}{c}\text { Cane } \\
\text { bluestem }\end{array}$ & 0.29 & 0.61 & 1.28 & 0.39 \\
$\begin{array}{c}\text { Broom } \\
\text { snakeweed }\end{array}$ & 0.55 & 0.33 & 1.85 & 0.62 \\
$\begin{array}{c}\text { Fourwing } \\
\text { saltbush }\end{array}$ & 0.29 & 0.50 & 0.65 & 1.22 \\
\hline & 0.19 & 0.54 & 1.39 & 1.25 \\
\hline
\end{tabular}


grass species. This is attributed to growth form and plant surface characteristics since cane bluestem's culms are often in large clumps. The culm nodes are bearded, but the leaves are essentially glabrous and linear (Gould 1975).

For grass species, 2 of the 4 independent variables (green and dry weight) were the most highly correlated with the amount of intercepted water (Table 3). Plant height had the lowest correlation while diameter was intermittent. For any 1 independent variable, the $R^{2}$ values were not much different between species. Tvalues were high for green weight, dry weight, and diameter which indicates a high probability that 1 or more of the coefficients is not zero.

\section{Broom Snakeweed}

Individual broom snakeweed plants ranged from large to small (Table 2) relative to green weights, dry weights, crown diameters, and heights. Gay et al. (1980) stated that this species grows to 60 $\mathrm{cm}$ tall. Therefore, the tallest samples for this study $(68 \mathrm{~cm})$ exceeded the maximum for this species. The mean values for green and dry weights, crown diameters, and plant heights were closer to the minimum than to the maximum values, and the coefficients of variation indicate that the sample represented many plant sizes. The coefficient of variation was not as high for broom snakeweed crown cover and height as for green and dry weights. The best prediction equation for broom snakeweed with the variables selected for inclusion is:

$$
\begin{aligned}
& \hat{y}=-2.645+0.594 \text { (dry wt. g) } \\
& \mathbf{R}^{2}=0.883 \quad \text { Std. Error }=26.310
\end{aligned}
$$

The ratio of intercepted water to green weight and dry weight (Table 4) was low for broom snakeweed compared to other plant species, except Russian thistle. This is attributed to growth form since broom snakeweed has erect linear leaves growing from erect stems (Stubbendieck et al. 1992).

\section{Fourwing Saltbush}

Individual fourwing saltbush plants ranged from large to small (Table 2) relative to green weights, dry weights, crown diameters, and heights. Gay et al. (1980) stated that this species grows to $180 \mathrm{~cm}$ tall. Therefore, the tallest samples for this study $(100 \mathrm{~cm})$ were considerably less than the maximum for this species. Crown diameters and plant heights were not as variable as green and dry weights for this species. The mean values for green and dry weights, crown diameters, and plant heights were closer to the minimum than to the maximum values, and the coefficients of variation indicate that the sample represented many plant sizes. The best prediction equation for fourwing saltbush with variables selected for inclusion is:

$$
\begin{aligned}
\hat{y}= & -13.93+0.158 \text { (green wt. g) } \\
& +1.040 \text { (diameter cm) } \\
R^{2}= & 0.986 \quad \text { Std. Error }=11.42
\end{aligned}
$$

The ratio of intercepted water to green weight and dry weight (Table 4) was low for fourwing saltbush compared to other plant species, but higher than broom snakeweed. This is attributed to growth form since fourwing saltbush has oblong to obovate or lanceolate leaves with stems that are sulcate or rough, and pubescent when young (Stubbendieck et al. 1992).

All of the independent variables associated with broom snakeweed had $\mathrm{R}^{2}$ values less than 0.800 (Table 3 ). Height was more highly correlated for broom snakeweed than any other species in the study except fourwing saltbush. T-values were high for all independent variables for both species.

Species in all 3 plant groups (forb, grass, and shrub) had different variables included in the prediction equations. However, dry and green weight were the 2 variables that appear to have the strongest relationship with the amount of water intercepted. Of the 10 species evaluated, dry or green weights were part of all equations, and height was included in only 4 equations. Tromble (1983a) found green weight followed by crown area and stem dry weight to be the most important variables affecting interception by tarbush (Flourensia cernua DC). In a study on creosotebush (Larrea tridentata (D.C.) Cov.), Tromble (1983b) found green weight of leaves and leaf area were the 2 most highly correlated variables followed by dry weight of leaves, total shrub green weight, dry weight of stems, number of stems, crown cover, green weight of stems, and volume. Shrub height was not correlated with the amount of intercepted water. The weight of water intercepted per weight of green or dry plant weight appears to be a function of plant growth form and surface characteristics rather than seral position.

Maximum potential interception capacity can now be calculated for a plant community that includes these common species if plant sizes and density are known for each species.

\section{Literature Cited}

Aston, A.R. 1979. Rainfall interception by eight small trees. J. Hydrol. 42:383-398.

Branson, F.A., G.F. Gifford, K.G. Renard, and R.F. Hadley. 1981. Rangeland hydrology. Kendall/Hunt Publ. Co., Dubuque, Iowa.

Brooks, K.N., P.F. Ffolliott, H.M. Gregersen, J.L. Thames. 1992. Hydrology and the management of watersheds. Iowa State Univ. Press, Ames, lowa 50010.

Calder, I.R. 1986. A stochastic model of rainfall interception. J. Hydrol. 89:65-71.

Gay, C.W., Jr., D.D. Dwyer, C. Allison, S. Hatch, and J. Schickedanz. 1980. New Mexico Range Plants. New Mexico State Univ. Cooperative Ext. Ser. Cir. 374.

Gould, F.W. 1975. The grasses of Texas. Texas A\&M Univ. Press, College Sta., Tex.

Harr, R.D. 1983. Potential for augmenting water yield through forest practices in western Washington and western Oregon. Water Resour. Bull. 19:383-393.

Herwitz, S.R. 1985. Interception storage capacities of tropical rainforest canopy trees. J. Hydrol. 77:237-252.

Leonard, R.E. 1965. Mathematical theory or interception. In Proc. International Symp. Forestry Hydrology, Pergammon Press, New York.

Miller, D.H. 1977. Water at the surface of the earth. Academic Press, New York.

Pitman, J.I. 1989. Rainfall interception by bracken in open habitats-relations between leaf area, canopy storage and drainage rate. J. Hydrol. 105:317-334.

Stubbendieck, J., S.L. Hatch, and C.H. Butterfield. 1992. North American range plants. Univ. Nebraska Press, Lincoln, Neb.

Teklehaimanot, Z., P.G. Jarvis, and D.C. Ledger. 1991. Rainfall interception and boundary layer conductance in relation to tree spacing. $J$. Hydrol. 123:261-278.

Thurow, T.L., W.H. Blackburn, S.D. Warren, and C.A. Taylor, Jr. 1987. Rainfall interception by midgrass, shortgrass, and live oak mottes. J. Range Manage. 40:455-460.

Tromble, J.M. 1983a. Interception of rainfall by tarbush. J. Range Manage. 36:525-526

Tromble, J.M. 1983b. Interception of rainfall by creosotebush (Larrea tridentata). Proc. XIV Intl. Grassl. Congr., Lexington, Ky.

Zadroga, F. 1981. The hydrological importance of a montane cloud forest area of Costa Rica. In: Lal, R. and F.W. Russell (eds.) 1981. Tropical Agricultural Hydrology, John Wiley and Sons, New York, N.Y. 